\title{
Monitoring the Activity of Feed Enzymes in Vitro and Their Activity in the System that Modulates the GIT
}

\author{
Valeriy Sergeevich Kryukov ${ }^{1}$, Ilona Vyacheslavovna Glebova ${ }^{2}$, Sergej Vladimirovich Zinoviev ${ }^{3}$ \\ ${ }^{1}$ LLC Vetpharmstandart, Moscow, Russian Federation \\ ${ }^{2}$ Kursk State Agricultural Academy, Kursk, Russian Federation \\ ${ }^{3}$ FSC "VNITIP" RAS, Sergiev Posad, Moscow, Russian Federation
}

Email address:

kryukov.v.s@mail.ru (V. S. Kryukov), snow1968@inbox.ru (I. V. Glebova), neollit_13@mail.ru(S. V. Zinoviev)

\section{To cite this article:}

Valeriy Sergeevich Kryukov, Ilona Vyacheslavovna Glebova, Sergej Vladimirovich Zinoviev. Monitoring the Activity of Feed Enzymes in Vitro and Their Activity in the System that Modulates the GIT. Ecology and Evolutionary Biology. Vol. 4, No. 3, 2019, pp. 33-38. doi: $10.11648 /$ j.eeb. 20190403.12

Received: June 26, 2019; Accepted: September 16, 2019; Published: October 23, 2019

\begin{abstract}
Their activity was studied under in vitro conditions simulating the gastrointestinal tract of the poultry. A decrease in the temperature of the medium from $50^{\circ} \mathrm{C}$ to $38^{\circ} \mathrm{C}$ reduced the activity of all enzymes. Fekord 2004-S, Agrocell Plus, Agrocell, Rovabio max AP, Xibeten-Gel, Axtra XAP 101 TPT, Endofeed DC at pH $3,38^{\circ} \mathrm{C}$ retained the highest initial xylanase activity: $81,80,70,70$, 67, 67, 65\% respectively. The minimum stability at pH 3 was established for Sunzyme, Hostazym C-100, Ronozyme VP, Natugrain TS and Ronozyme WX: 46, 44, 42, 40, and 38\%, respectively. At $\mathrm{pH} 7,38^{\circ} \mathrm{C}$ it was better activity than the average for all preparations showed C Axtra XAP 101 TPT, Fekord-2004-C, Econase XT-25, Agrocell: 52, 47, 47, 45\%; minimal activity was shown by Rovabio Exel AR, Cellulase, Cellolux F, Sunzaim: 4, 5, 7, and 8\%, respectively. An outstanding high activity of cellulase at $\mathrm{pH} 3,38^{\circ} \mathrm{C}$ was found in Fekord 2004-C - 90\%, above the average value it was in Econase XT 25 , Acra


Rovabio Max AR, Cellolux F and Xybeten-Cel: 20, 23, 23 and 25\%. At pH 7, $38^{\circ} \mathrm{C}$, the maximum activity of most enzymes remained within 30\%, excluding Hostazym S-100 - 52\%. The minimum glucanase activity at pH 7 was shown by Rovabio Max AP - 4\%, Xybeten-Cel - 5\%, Endofeed DC - 6\%, and Rovabio Exel AP -6\%. The average activity of cellulase for all studied enzymes was $19.1 \%$ of that determined at $\mathrm{pH}$, and 50C. Under all experimental conditions, the activity of xylanases of the studied enzymes was mainly better than glucanases. This indicates greater cellulases stability. It has been substantiated that the activity indicated by the manufacturer serves only for labeling the product and does not reflect its action in the body. Used matrix values of enzymes are intended for commercial purposes and weakly reflect the real effect of enzyme.
\end{abstract}

Keywords: Feed Enzymes, Activity Enzymes, Choice Feed Enzymes, Matrix Values Enzymes

\section{Introduction}

Feed enzymes began to use in Russia since the beginning of this century. At that time, three-four foreign companies and two Russian manufacturers were present in the Russian market, the competition between them was small, and the purchases were not impressive. Gradually, knowledge and culture of the use of enzymes grew. Among feed enzymes phytase, was created predominantly for use in animal feeding. All other enzymes were originally developed for use in industrial applications and were subsequently offered as feed additives. Their use in industry is many times higher than their share in feed production.

\section{Comparison of the Activity of Feed Enzymes}

\subsection{About Methods for Determining the Activity of Enzymes}

Manufacturers of enzymes do not take into account the peculiarities of digestion of animals, so they offer products 
which are not always effective. Enzyme preparations, created for industrial purposes, exhibit maximum effect in conditions that are far from corresponding to the environment in which they fall in the gastrointestinal tract (GIT). The predominant use of enzymes in the industry confirm the methods of monitoring the activity of enzymes, which in most cases is determined at a temperature of about $50-55^{\circ} \mathrm{C}$ and $\mathrm{pH} 5.0-$ 5.5. These conditions correspond to industrial technological regulations. In the GIT, the temperature will be much lower, and the environment is changing in the course: crop stomachs - intestines. The GIT contains its own digestive enzymes that digest proteins and, in particular, can digest the added enzymes that have different resistance to the action of GIT proteases $[1,2]$.

\subsection{The Results of the Comparative of Activity of Enzymes from Different Manufacturers}

In the Moscow State University in the study of 24 enzymes preparations, of the most common in the Russian market, found that the activities of endo- $\beta-1,4$-glucanase and endo- $\beta$ 1,4-xylanase in an environment that simulates $\mathrm{pH}$ and temperature of gastro-intestinal tract, was 57,3 and 42,8\% lower, respectively, against activity determined at $\mathrm{pH} 5$ and temperature $50^{\circ} \mathrm{C}$. In some enzymes, the activity of glucanase in gastric conditions in some preparations was 75 $80 \%$ lower than at pH 5 and a temperature of $50^{\circ} \mathrm{C}$, - in 6 of them it decreased by $35-45 \%$ and only one enzyme $-10 \%$ (table 1) [3].

Table 1. The activity of enzymes that was determined under conditions similar to those of manufacturer's und in conditions simulating the temperature and pH of the stomach and intestines

\begin{tabular}{|c|c|c|c|c|c|c|c|c|}
\hline \multirow{3}{*}{ № } & \multirow{3}{*}{ Feed enzymes } & \multirow{3}{*}{$\begin{array}{l}\text { Country of } \\
\text { origin }\end{array}$} & \multicolumn{2}{|c|}{ Activity at, $5^{\circ} \mathrm{C}, \mathrm{pH} 5$, u./g } & \multicolumn{4}{|c|}{ Activity at $38^{\circ} \mathrm{C}$ in $\%$ of determined at $50^{\circ} \mathrm{C}$, pH 5} \\
\hline & & & \multirow{2}{*}{ Gluca-nase } & \multirow{2}{*}{ Xyla-nase } & \multicolumn{2}{|c|}{ Glucanase } & \multicolumn{2}{|c|}{ Xylanase } \\
\hline & & & & & pH 3,0 & pH 7,0 & pH 3,0 & pH 7,0 \\
\hline 1 & Фекорд-2004-С (Fekord-2004-С) & Belarus & 80 & 290 & 90 & 33 & 81 & 47 \\
\hline 2 & Агроцелл Плюс (Agrocell plus) & Russia & 4100 & 1050 & 56 & 32 & 80 & 42 \\
\hline 3 & Акстра XВ 201 ТРТ & US & 1300 & 780 & 62 & 11 & 62 & 45 \\
\hline 4 & Econase XT 25 & Finland & 65 & 2100 & 63 & 13 & 54 & 47 \\
\hline 5 & Агроксил Плюс (Agroxil plus) & Russia & 1100 & 4100 & 60 & 35 & 54 & 32 \\
\hline 7 & Vilzim & Mexico & 2180 & 11000 & 58 & 12 & 52 & 28 \\
\hline 8 & Агроцелл (Agrocell) & Russia & 4200 & 1040 & 40 & 25 & 70 & 45 \\
\hline 9 & Rovabio Max AP & France & 1480 & 2720 & 23 & 4 & 70 & 8 \\
\hline 10 & Xybeten-Cel & Bulgaria & 4000 & 610 & 25 & 5 & 67 & 0 \\
\hline 11 & Axtra XAP 101 TPT & Finland & - & 1800 & - & - & 67 & 52 \\
\hline 12 & Endofeed DC & Spain & 580 & 1000 & 31 & 6 & 65 & 26 \\
\hline 13 & Cellulase & China & 5870 & 500 & 39 & 31 & 62 & 5 \\
\hline 15 & Агроксил (Agroxil) & Russia & 1100 & 5100 & 44 & 38 & 60 & 25 \\
\hline 16 & ROXAZYME G2G & Switzerland & 350 & 720 & 46 & 32 & 58 & 17 \\
\hline 17 & Rovabio Exel AP & France & 1490 & 2850 & 20 & 6 & 57 & 4 \\
\hline 18 & Xybeten-Xil & Bulgaria & 1600 & 4000 & 33 & 32 & 56 & 10 \\
\hline 19 & Фекорд-2012-Ф (Feocord-2012-F) & Belarus & 400 & 200 & 52 & 27 & 47 & 32 \\
\hline 20 & Sunzyme & China & 1450 & 4100 & 34 & 28 & 46 & 8 \\
\hline 21 & Hostazym C-100 & Bulgaria & 500 & 100 & 40 & 52 & 44 & 17 \\
\hline 22 & Ronozyme VP & Denmark & 130 & 150 & 35 & 37 & 42 & 29 \\
\hline 23 & Natugrain TS & Germany & 225 & 1980 & 43 & - & 40 & - \\
\hline 24 & Ronozyme WX & Denmark & 15 & 970 & - & 30 & 38 & - \\
\hline \multicolumn{2}{|c|}{ Average } & & & & 44,2 & 19,1 & 57,8 & 30,6 \\
\hline
\end{tabular}

In general, the activity of endo- $\beta-1,4$-xylanases in the stomach was higher than that of glucanases, and the decrease in activity in xylanases was not the same with glucanases: in some cases, it decreased more progressively and in others vice versa. When enzymes aged in an acidic medium in the presence of pepsin for 30 and 120 minutes, their activity continued to decrease, but most enzymes to a lesser extent than initially under the influence of a lower temperature [3]. Whether this was due to the digestion of enzymes under the action of pepsin or caused by the structural changes in the enzyme in an acidic environment, remains unclear. It is interesting to note that the activity of the studied enzymes at $\mathrm{pH} \mathrm{7,} \mathrm{which} \mathrm{is} \mathrm{close} \mathrm{to} \mathrm{the} \mathrm{environment} \mathrm{of} \mathrm{the} \mathrm{intestine,} \mathrm{was}$ significantly lower than in the acidic environment of the stomach, the latter should be given a negative assessment, since most of the time the feed is in the intestine, where it is digested.

\subsection{Discussion}

Scientists and experts in recent years, focus on the fact that the activity of enzymes and their action - reflect different concepts. It should be noted that the units characterizing the activity are provided for the purposes of marking commercial products, and have no value for comparing their properties [4]. Creates confusion by expressing activity in units of different dimensions. So, only to indicate the activity of xylanase, 9 different units are known [3]. The activity of the enzyme specified by the manufacturer, characterized by the ability to produce a certain effect in a particular standard conditions of analysis, which always differ from the conditions occurring in the body, so the activity set by the manufacturer, does not coincide with its manifestation in the 
GIT, and is not a reliable way to identify the comparative effectiveness of feed enzymes [4]. As a result of the evolution of animals, such conditions were created for the digestion of food that, when passing the feed through the gastrointestinal tract, new enzymes are released at each stage, and one enzyme does not work throughout the digestive tract. This is especially evident in proteases: pepsin acts on proteins in the stomach and is not active in the intestines, in which protein digestion continues under the trypsin, and then peptidases. Industrial feed enzymes have specific properties, they are active in certain conditions and are not adapted for action throughout the digestive tract. In this regard, the activity of commercial enzymes, measured in an in vitro model solution, cannot be used to assess the effectiveness of their action in the digestive tract as a whole [5].

According to the manuals for the use of feed enzymes, which are approved by the «Rosselkhoznadzor» of the Russian Federation, the activity of enzymes is indicated on the basis of the declaration of the manufacturer (supplier) they are indicated in the form of some units, without indicating their dimension. In results conclusions about the effectiveness of drugs can only be made on the basis of animal test. The results can be further reproduced if the enzyme is used in similar conditions, the main ones being the composition of the diet and the age of the animals. Failure to comply with these requirements leads to conflicting conclusions about the effectiveness of one and the same enzyme. It is unacceptable to transfer the results to enzymes of the same purpose, but purchased from different manufacturers.

Many scientific publications have reported that the use of feed enzymes stimulates feed intake this conclusion is in most cases true if they are used with reduced energy or protein content. If the diet contains enough energy, increasing its availability as a result of the action of enzymes will lead to a decrease in feed intake and possibly a lack of other nutricins.

The effectiveness of enzymes depends not only on the ability to digest the target substrates, but also on the amount of other nutrients that being associated with substrates cannot be digested. There are direct and indirect actions by which enzymes digesting non-starch polysaccharides (NSP) improve productivity. The first has little effect on the additional energy supply to the body. The most important is the indirect effect, which is associated with a decrease in the anti-nutritional properties of non-starch polysaccharides as a result of their decomposition. This eliminates the encapsulating effect of the cell wall and reduces the viscosity of the intestinal contents. As a result, the availability of pancreatic enzymes to intracellular starch, which is the main source of energy, increases. The hydrolysis products of the cell wall polysaccharides, partially represented by monosaccharides, are absorbed while the oligosaccharides have prebiotic properties. They are converted by microflora to volatile fatty acids, which are absorbed and are a source of energy; in addition they lower the $\mathrm{pH}$, which inhibit the proliferation of coliform bacteria. At the same time, the formation of butyric acid promotes the growth of brush border microvilli [6]. At the same time, the population of microorganism's decreases, which leads to a decrease in their consumption of nutrients, was increasing their availability to the animal.

Taking into account the diversity of the structure and composition of plant feed cells and the properties of enzyme preparations, it can be assumed that some combination of enzymatic activities will be effective. It is rather difficult to choose enzymes for including in a multienzyme product; any enzyme preparation with a special purpose, in addition to increasing the availability of its substrates, partially overcomes its anti-nutritional effect. The answer to the use of enzymes is always multifactorial. If we exclude the extreme case - the inactivation of enzymes, then they always subject to digestion the substances they are aimed at, that is, show their properties. The lack of zootechnical results can be associated with an unsuccessful choice of enzymes, a violation of the technology of their use or enzyme-induced imbalance of nutrients absorbed into the body.

\section{Choice of Enzymes}

Animals digest from 75 to $80 \%$ of the organic matter of the feed - the remaining inaccessible part is the target of the effects of enzyme preparations, that is, feed enzymes or multienzyme preparations are designed so that they act on the indigestible part of the feed. The composition of the undigested fraction varies depending on the components of the diet and the physiological characteristics of digestion. For a more reliable choice of feed enzymes, it is necessary to have a characteristic of the undigested part of the feed. Choosing enzymes on the basis of their specificity, they lose the features of the action of enzymes in the GIT, which has additional effects that are not related to their specificity [7]. Enzymes have to be chosen on the basis of the current availability of feed raw materials, as well as the expected content of substrates in it and the age-related characteristics of digestion.

The market of feed enzyme preparations is striking in variety, which creates difficulties in terms of elucidating their action and interaction in the digestive tract, in order to predict productivity.

Examples can be given when, when developing multienzyme preparations, their effect turned out to be no better than products containing one of the tested enzymes [8], although there are opposite examples [9]. There is a pattern that confirms the diminishing effectiveness of the subsequent addition of each new activity to a multienzyme preparation; therefore, the effect of multienzyme additives cannot be predicted by adding up the effectiveness of each enzyme. [10]

\section{About Matrix Values of Enzymes}

In practical terms, the effectiveness of specific enzyme preparations is characterized by the magnitude of the increase in the availability of metabolic energy, amino acids, 
phosphorus, calcium from feed, i.e. matrices. In order to choose and apply the enzyme preparation correctly, it is necessary to understand what justifies the values presented in the matrix. The development of matrixes is difficult because, as described above, enzymes are characterized not only by their direct action on target substrates, but also by indirect influence. The considerable range of variability of the quantities characterizing the splitting of substrates of grain significantly complicates the forecast of an increase in the availability of nutrients. From this it follows that it is impossible to reflect the action of the enzyme on different types of raw materials with a single matrix, whose shares in mixed feeds are variable.

In studies on pigs, it was concluded that using a matrix with a fixed value for different types of diets is not recommended, as this may lead to the development of an inadequate diet [9].

In scientific studies, some cases have observed the lack of advantages of the enzyme compositions tested, compared with preparations with a single activity. Thus, the inclusion of 2-3 enzyme preparations in the compound feed recipe on the basis of information about the action of each individual to increase productivity is not always justified [10-14]. Effective combinations of the activities must be established in scientific trials and then confirmed in practical terms. Based on the work carried out, the matrix values of the action of multienzyme preparations can be determined, which will be inherent only in a specific combination of activities and only for feeds of similar composition, which used in the development of a multienzyme preparation recipe.

Preparing feed recipes using computer programs, use the matrix values of enzyme preparations that are entered into the database of raw materials. There are two ways to represent matrix values that reflect the action of enzymes: 1 - by influence and 2 - by composition. The first method reflects the magnitude of the increased availability of nutrients in the feed and is expressed more often in percent. It is advisable to calculate the effect of the enzyme separately on the main types of raw materials (wheat, corn, meals, and other macrocomponents). The second method is in composition, easier for the recipe developer, because it provides for a change in the nutritional value of the entire diet. In the second method, matrix values are represented by virtual quantities, assuming that from $0.1-0.5 \mathrm{~g}$ of the enzyme per kilogram of feed 40 $80 \mathrm{kcal} / \mathrm{kg} \mathrm{ME}$ will be added, available lysine $-30-60 \mathrm{mg}$, available methionine - 10-20 mg, phosphorus - $600-1100 \mathrm{mg}$. Of course, these quantities are not added to the feed with a small dose of the enzyme. It is assumed that the availability of nutrients of the feed will increase by such quantities, with the inclusion of an enzyme in it. In our opinion, this method with its simplicity has an important disadvantage: it is worse adapted to take into account the change in the ratio of the main raw material in the recipe and therefore the risk of obtaining an inadequate recipe is higher.

If we return to the definition of the notion of a matrix, this word, put into using by enzyme promoters, did not add anything new to their properties and it is quite possible to do without it. Nutritional tables of raw materials are also its matrixes. It can be said that the nutritional matrix of wheat, oilcake, etc., however, despite the fact that the nutritional value of the same oilcake or wheat has already been determinate many times, experts on feeding each time a new batch of raw materials arrives, send it to the laboratory to establish the actual composition, There is to adjust the nutritional matrix. This technique has become an unwritten rule. The question arises: why do they constantly use enzyme matrixes that were once determined somewhere or simply calculated and not adjusted? The question can be continued: how much do we need such matrixes? The official manuals for the use of enzymes contain data on the composition of enzyme preparations and their activity and recommended doses of the enzyme. But in none of the manuals do they cite enzyme matrixes, because enzyme producers as opposed to sellers cannot specify their fixed values, since the values of the matrixes are not official and are only suitable for advertising purposes.

Materials and test protocols used in the development of matrixes should be available to consumers. The results of their development should be presented to customers and based on many replications. In this case, results will be obtained in some range of fluctuations - this is natural, and the developer must explain to the customer why in some cases the effect of the enzyme preparation was high, and in others - weak, and how to achieve the greatest efficiency. The maximum results obtained by the developer in ideal circumstances are the target for the consumer, which can be achieved, but they are not mandatory. In order to achieve the greatest result, it is necessary to turn not to matrixes, but for recommendations to specialists in maintenance.

\section{Matrix Application Problems}

In recent years include in the diet 2-3 enzyme preparations. In this case, there are misunderstandings regarding the assessment of their possible effectiveness and errors in predicting the expected productivity. The effect of adding each new enzyme depends on the amount of substrate present in the feed. In addition, one enzyme, for example, cellulase, destroying cellulose cell membrane, increases the possibility for the action of other enzymes whose substrates are located inside the cell. However, the xylanase and pectinase destroy the cell membrane; therefore, any of the enzymes that destroy the cell membrane in other ways will reduce the possibility of this effect appearing as a result of the action of another enzyme. None of the calculations can predict the effect of the sum of several enzymes in the diet. The most widely used enzymes in growing young animals. It is difficult to predict the effectiveness of their actions, due to active changes in the digestive system at an early age [15]. It is especially difficult to develop a "correct" matrix characterizing any enzyme for broiler chickens and piglets after weaning age. Using the example of changes in the use of energy of the metabolizable energy from the same wheat, it was found that the 7-day-old chickens had an ME value of 2,637kcal $/ \mathrm{kg}$, at 21-day-old - 
$2,748 \mathrm{kcal} / \mathrm{kg}$ and in 35 days - 2,933 kcal $/ \mathrm{kg}$. A significant increase in the availability of ME with age shows that the digestive system is actively changing at this time, achieving optimum nutrient recovery from feed by 35 days [16]. When developing rations, they usually use the same ME value, taken from reference books or calculated on the basis of nutrient digestibility factors established in balance experiments at any one age. Such approach to the calculation of the nutritional value of the feed and the influence of enzymes on it does not guarantee success in predicting productivity.

\section{Conclusion}

Evaluation and selection of enzymes for use in feeding animals is difficult due to the fact that their activity is determined by manufacturers using different methods that differ significantly. The paradox also lies in the fact that the activity of enzymes is characterized by units, and the recommended doses are expressed in grams. Enzymes are widely represented on the feed market, but consumers do not have a reliable tool to pre-select the appropriate enzyme. As a result, enzymes are often bought based on information from sellers and their ability to represent the product offered. This article presents the results of a study of the activity of certain glucanases and xylanases, which was determined in vitro under the same conditions: $\mathrm{pH} 5$ and a temperature of $50^{\circ} \mathrm{C}$. Due to the fact that the activity of the preparations was significantly different, its change under the influence of $\mathrm{pH}$ and temperature was expressed as a percentage from established at $\mathrm{pH} 5$ and a temperature of $50^{\circ} \mathrm{C}$. The results showed that lowering the temperature to $38^{\circ} \mathrm{C}$ both at $\mathrm{pH} 3$ and 7 reduced the activity of glucanase and xylanase, and in some feed enzymes it was more active, and in others decreased to $4-8 \%$, that is, to insignificant values.

In all cases, an increase in the $\mathrm{pH}$ of the medium from 3 to 7 led to a decrease in the activity of glucanase and xylanase. The data presented make it possible to calculate the natural activity of the studied enzymes and, depending on the recommended dose, calculate the activity shown by the enzyme. Based on the cost of the feed enzyme and the established activity, the consumer can navigate when choosing an enzyme preparation or reduce their number for subsequent testing on animals.

The use of feed enzymes is aimed at increasing the digestibility of difficultly digestible or indigestible food residues. However, the action of enzymes, as a rule, is studied by adding to the original feed, which does not allow to clearly identifying the action potential of the enzyme. It is necessary to isolate undigested feed residues from feces and to test the effects of feed enzymes on them. This method has not yet been used by scientific workers, but it will allow obtaining more clear information about the need and effectiveness of enzyme preparations.

Recommended matrix values for accounting for the action of enzymes are more associated with advertising techniques that affect the success of enzyme sales than with an assessment of their action. The real effectiveness of the use of a specific enzyme preparation can be determined in specific conditions on the animals, taking into account the age, conditions of detention and composition of feed raw materials, as well as nutritional value of the diet.

\section{Conflict of Interest}

All the authors do not have any possible conflicts of interest.

\section{References}

[1] Inborr J. and Grönlund A. 1993. Stability of feed enzymes in physiological conditions assayed by in vitro methods. Agric. Sci. Finl. Vol. 2. p. 125-132.

[2] Kryukov V. S., Glebova I. V., Antipov A. A. Evaluation of fitases action in gastrointestinal tract and the use of fitase preparations in animal feeding: a review. Problems of Productive Animal Biology, 2019. No2. P. 19-43.

[3] Volchok A. A., Korotkova O. G., Kondratyev E. G., Kryukov V. S., Sinitsyna O. A., Sinitsyn A. P., Shashkov I. A. The activity of glucanases and xylanases of feed enzyme preparations in the gastrointestinal tract of poultry. J. "Poultry farming." 2018. No04. S. 39-45.

[4] Vasquez M. V. and Glitsoe V. Phytase Unit Myth! 2012. https://www.dsm.com/content/dam/dsm/anh/en_US/document s/2012_Phytase_unit_myths.pdf.

[5] Menezes-Blackburn D., Gabler S., Greiner R. Performance of Seven Commercial Phytases in an in Vitro Simulation of Poultry Digestive Tract. J. Agric. Food Chem. 2015. Vol. 63. P. 6142-6149.

[6] Masey O’Neill H. V., Smith J. A. and Bedford M. R. Multicarbohydrase enzymes for non-ruminants. Asian-Australas. J. Anim. Sci. 2014. Vol. 27. p. 290-301.

[7] Bedford M., Schulze H. 1998. Exogenous enzymes for pigs and poultry. Nutr Res Rev. 1996. Vol. 11. P. 91-114.

[8] Kalmendal, R. and R. Tauson. Effects of a xylanase and protease, individually or in combination, and an ionophore coccidiostat on performance, nutrient utilization, and intestinal morphology in broiler chickens fed a wheat-soybean mealbased diet. Poult. Sci. 2012. Vol. 91. p. 1387-1393.

[9] Zuo J., Ling B., Long L., Li T., Lahaye L., Yang C., Feng D. Effect of dietary supplementation with protease on growth performance, nutrient digestibility, intestinal morphology, digestive enzymes and gene expression of weaned piglets. J. Animal Nutrition. 2015. Vol. 1. p. 276-282.

[10] Ingelmann C.-J., Witzig M., Möhring J., Schollenberger M., Kühn I., Rodehutscord M. Effect of supplemental phytase and xylanase in wheat-based diets on prececal phosphorus digestibility and phytate degradation in young turkeys. Poultry Science. 2018. Vol. 97. p. 2011-2020.

[11] Roofchaei A., Rezaeipour V., Vatandour S., Zaefarian F. Influence of dietary carbohydrases, individually or in combination with phytase or an acidifier, on performance, gut morphology and microbial population in broiler chickens fed a wheat-based diet. Animal Nutrition. 2019. Vol. 5. p. 63-67. 
[12] Kalmendal R. and Tauson R Effects of a xylanase and protease, individually or in combination, and an ionophore coccidiostat on performance, nutrient utilization, and intestinal morphology in broiler chickens fed a wheat-soybean meal-based diet. Poultry Sci. 2012. Vol. 91.p. 1387-1393.

[13] Alagawany M., Elnesr Sh. S., Farag M. R. The role of exogenous enzymes in promoting growth and improving nutrient digestibility in poultry. Iran J. Vet. Res. 2018 Vol. 19. p. $157-164$.

[14] Torres-Pitarch A., Manzanilla E. G., Gardiner G. E.,
O'Doherty J. V. Lawlor P. G. Systematic review and metaanalysis of the effect of feed enzymes on growth and nutrient digestibility in grow-finisher pigs: Effect of enzyme type and cereal source. Animal Feed Science and Technology. 2019. Vol.251. p. 153-165.

[15] Noy Y. and Sklan D. Digestion and Absorption in the Young Chick. Poultry Sci. 1995. Vol. 74. p. 366-373.

[16] Bedford, M. R. The effect of enzymes on digestion. J. Appl. Poult. Res. 1996. Vol. 5. P. 370-378. 